\title{
Measures taken by Veterinarians in Sweden in Cases of Bovine Mastitis
}

\author{
By T. Ekman, G. Åström and H. Funke
}

Department of Obstetrics and Gynaecology, Faculty of Veterinary Medicine, Swedish University of Agricultural Sciences, Uppsala, Sweden.

\begin{abstract}
Ekman, T., G. Åström and H. Funke: Measures taken by veterinarians in Sweden in cases of bovine mastitis. Acta vet. scand. 1994, 34, 329-335. - A questionnaire concerning the diagnosis and treatment of bovine mastitis was sent to all 350 Swedish food animal practitioners. $287(82 \%)$ of the questionnaires were returned. One of the main aims was to establish if Swedish food animal practitioners used a common therapeutic regime that could be used as a control treatment in future clinical trials.

It was found that many factors of importance for the clinical diagnosis of mastitis such as body temperature, duration of the symptoms etc. often were not considered. On the other hand $60-70 \%$ of the practitioners regularly took milk samples to obtain a bacteriological diagnosis. Approximately $40 \%$ of the veterinarians cultured the milk samples in their home laboratory.

Basic measures like frequent emptying of the udder were recommended by only $40-50 \%$ of the veterinarians.

All responding field veterinarians used the systemic route for administering antibiotics when treating cases of acute, clinical bovine mastitis. The drug of choice, initially, in these cases was benzylpenicillinprocain, which was used by $65-75 \%$ of the veterinarians. Twentyfive percent used a broadspectrum antibiotic, most commonly a combination of penicillin and streptomycin. A minority $(5 \%)$ directed their initial therapy towards gramnegative bacteria.

About $30-40 \%$ supported the systemic therapy with intra-mammaries. Other drugs such as NSAID, corticosteroids and oxytocin was used, on a regular basis, by only about $10 \%$ of the practitioners.
\end{abstract}

clinical trial; questionnaire; treatment.

\section{Introduction}

Numerous clinical trials with the purpose to establish optimal use of chemotherapeutics in treatment of mastitis are found in the literature. Different chemotherapeutics, local and systemic administrations, various dose levels etc. have been evaluated (Breeuwsma et al. 1975, Dodd \& Griffin 1975, Funke 1979, Funke 1983, Bjorland et al. 1984, Holmgren et al. 1985, Craven 1987, Francis 1989, Jarp et al. 1989, Østerås et al. 1994). However, some of these and other trials may be criticized for inter alia faulty design, particularly inadequate controls and small sample size.

Field practitioners do not only use chemotherapeutics in their efforts to treat bovine mastitis. In their treatment regimens basic measures like frequent milkings and general care of the animal as well as basic therapy like administration of anti-inflammatory drugs, and, when necessary, rehydration may be in- 
cluded. In clinical trials this may of course affect the results (Andersson et al. 1986).

To be able to carry out large clinical trials field veterinarians are indispensable. Knowledge about their diagnostic procedures and treatment regimes is necessary if field trials are to be adequately designed and the results correctly evaluated. At least this is the case when a current standard therapy is to be used as a control.

The aim of the present study was to find out how cases of mastitis are diagnosed and treated by the Swedish field practitioners.

\section{Method}

All 350 Swedish food animal field practitioners were sent questionnaires regarding treatment of bovine mastitis. One half of the practitioners were presented with 7 different case stories of mastitis that they were asked how they would treat, and the other 175 were asked specific questions concerning diagnosis, treatment etc. It was made sure that the questionnaires could be returned anonymously to the authors.

The 7 different cases of mastitis were described in some detail. Acute, clinical mastitis was represented by 2 cases with relatively accentuated clinical symptoms like hard and swollen udder quarters, milk changes and raised body temperature.

One case of peracute mastitis was included. The cow was seriously affected and was described as being paretic and dehydrated and having increased pulse rate and temperature.

Exacerbative mastitis was represented by 3 cases having long histories of recurrent episodes of clinical symptoms from the udder and milk. The cows were otherwise rather unaffected. The economic values of the cows differed as they were of different ages and lactational stages. Prognostically they could also be put in different groups.

One high producing cow at her second lactation with infections with Staph. aureus and a
Table 1. Percent veterinarians stating what they consider of special importance for the diagnosis and for judging the prognosis in cases of clinical mastitis.

\begin{tabular}{lr}
\hline Factors & $\%$ \\
\hline Symptoms & \\
General condition of the animal & 52 \\
Body temperature & 31 \\
Appetite & 13 \\
Firmness of the udder & 31 \\
Appearance of the milk & 40 \\
CMT score & 13 \\
pH of the milk & 8 \\
Nos. of udder quarters affected & 3 \\
Digestive disturbances & 18 \\
Paresis & 9 \\
Anamnesis & \\
The development of the disease & 15 \\
The duration of the disease & 15 \\
Lactation stage & 26 \\
Earlier cell counts or CMT scores in the milk & 31 \\
Earlier infections in the udder & 33 \\
Earlier infections in the herd & 21 \\
Predisposing factors & \\
Teat damages & \\
The environment of the cow & \\
Fodder and water & 24 \\
Economic factors & 21 \\
Age of the cow & 17 \\
Value of the cow & \\
Production of the cow & \\
Recruitment of the herd & \\
Other factors & \\
Smell of the milk & \\
\hline & \\
\hline
\end{tabular}

Streptococcus $s p$. in her right front and right hind quarters, respectively, diagnosed 7 months back, and with bulk milk cell counts varying between 175,000 and $300,000 / \mathrm{ml}$ since then, was included. The cow represented a case of subclinical mastitis which had to be attended at drying off.

Of the questionnaires 287 (82\%) were recovered. The proportion of recovery was about equal in the 2 groups of practitioners. 
Table 2. Percent veterinarians applying basic measures and basic therapy to different cases of clinical mastitis.

\begin{tabular}{lccc}
\hline & $\begin{array}{c}\text { Acute } \\
\text { mastitis }\end{array}$ & $\begin{array}{c}\text { Peracute } \\
\text { mastitis }\end{array}$ & $\begin{array}{c}\text { Exacerbative } \\
\text { mastitis }\end{array}$ \\
\hline Basic measures: & & & 38 \\
Frequent milking & 53 & 41 & 12 \\
Massage with/without liniment & 14 & 3 & - \\
Drying off of a single udder quarter & - & 1 & \\
Basic therapy: & & & 2 \\
Oxytocin & 10 & 6 & 3 \\
Antiinflammatory drugs & 7 & 71 & - \\
B-vitamins & 1 & 6 & - \\
Glucose & 1 & - & - \\
Calcium & - & 97 & - \\
Liquids (p.o. or i.v.) & - & 36 & - \\
Carbon, lactic acid etc. & - & 29 & \\
\hline
\end{tabular}

The results were preliminary evaluated and discussed by Ekman et al. (1990, 1991), Funke et al. $(1990,1991 \mathrm{a}, \mathrm{b}$,$) and Åström et al.$ (1991).

\section{Results and discussion \\ Clinical diagnosis}

Factors of special importance for the diagnosis and for judging the prognosis in cases of clinical mastitis as pointed out by the veterinarians are shown in Table 1.

A general impression from Table 1 is that factors of importance in cases of clinical mastitis are commonly not considered by many veterinarians. There is a big gap between what is taught in the subject at the veterinary college and what is actually practised in the field. The fact that e.g. clinical symptoms and duration of infections and inflammations are of outmost importance as marksettings for the prognosis seems to be overlooked by many veterinarians. A more positive interpretation of the results could be that many veterinarians omit what they think are obvious acts when giving their answers in a questionnaire.

\section{Bacteriological diagnosis}

It was found that the interest to include bacteriological examinations in the diagnostic routines in cases of mastitis has increased during the last 20 years (Anon. 1975). In cases of acute mastitis $60-70 \%$ of the veterinarians regularly sampled for bacteriological diagnosis. About $40 \%$ of the veterinarians cultivated the milk samples and diagnosed the infectious agent in their home laboratories. In peracute cases and in cases of exacerbative mastitis this dropped to between 30 and $60 \%$ and at drying off the incidence of culturing a case of subclinical mastitis was $17 \%$. Thus cases that are thought to have a bad or guarded prognosis seemed to discourage the veterinarians to take samples for bacteriological diagnosis. A firm belief that gram negative infections are prevailing in cases of peracute mastitis and gram positive infections in cases of exacerbative mastitis and subclinical chronic mastitis may have contributed to a lower interest to sample these cases.

\section{Treatment}

Basic measures and basic therapy: 
The percentage of veterinarians practising different basic measures and basic therapy in cases of clinical mastitis in the cow is shown in Table 2.

Although it is well accepted that reduction of bacteria, toxins and inflammatory products in the udder by massage and frequent milkings constitutes the bases for successful treatment of mastitis, it was practised to a low extent. A common motive was that farmers do not have the time to do the job. Furthermore, oxytocin was relatively seldom used. This is probably partly due to the uncertainty as to the effects of oxytocin on inflamed udder tissues.

Antiinflammatory drugs were used mostly in cases of peracute mastitis. Corticosteroids, but also non steroidal anti-inflammatory drugs, like flunixin meglumine were used. In the case of the peracute mastitis with symptoms of paresis, toxinaemia and dehydration calcium therapy was practised by almost $100 \%$ of the veterinarians but for instance the need for rehydration seems to be overlooked by many colleagues.

Drying off of chronically infected udder quarters during early or mid lactation was very rarely done most probably due to the lack of an efficient and safe method.

Antimicrobial treatment. It has been estimated that in Sweden about $80 \%$ of infections isolated from cases of bovine mastitis are sensitive to benzylpenicillin (Robertsson et al. 1987). Benzylpenicillin preparations were therefore chosen as first hand preparations by $65-75 \%$ of the practitioners before the infections were properly diagnosed. Spiramycin, broad spectrum chemotherapeutics or combinations of chemotherapeutics were preferred by a minority of veterinarians. When gram negative infections were suspected (ca. $15 \%$ of the clinical mastitis cases) trimethoprim/sulfonamide preparations were used as first hand preparations by the majority of veterinarians $(70-80 \%)$. Enrofloxacin and combinations of chemotherapeutics i.e. benzylpenicillin and dihydrostreptomycin were also used. Those who had a laboratory in their home or clinic changed the initial treatment when necessary within $24 \mathrm{~h}$ when the infectious agent had been identified.

All (100\%) of the Swedish food animal field practitioners chose the systemic route for administering antibiotics when treating cases of acute, clinical bovine mastitis. Systemic treatment only was practised by $60-70 \%$ of the veterinarians. A combination of systemic and local treatment was used by $30-40 \%$. One reason for the extensive use of systemic treatment in Sweden is the well documented uniform distribution in the udder tissue of chemotherapeutics after systemic treatment and the uneven distribution after local treatment in cases of acute and chronic mastitis (Funke 1961, Rasmussen 1964, Owens \& Nickerson 1990). A second reason is that systemic treatment makes a combination of chemotherapy and frequent milkings possible. A third reason could be the risks of negative effects on the immune system by high concentrations of some chemotherapeutics when infused locally in the udder (Nickerson et al. 1986, Craven 1987).

The dose of chemotherapeutics and duration of treatment practised by veterinarians in a case of acute clinical mastitis is shown in Fig. 1. It is seen that benzylpenicillinprocain alone was most commonly used. In general the doses tended to exceed the recommended doses by $25 \%$ or more when pure benzylpenicillin preparations were used. It was also common to underdose benzylpenicillin-procain-dihydrostreptomycin preparation. From other cases it was found that underdosing of spiramycin, tetracyclin and trimethoprim/sulfonamide was more a rule than an exception. 


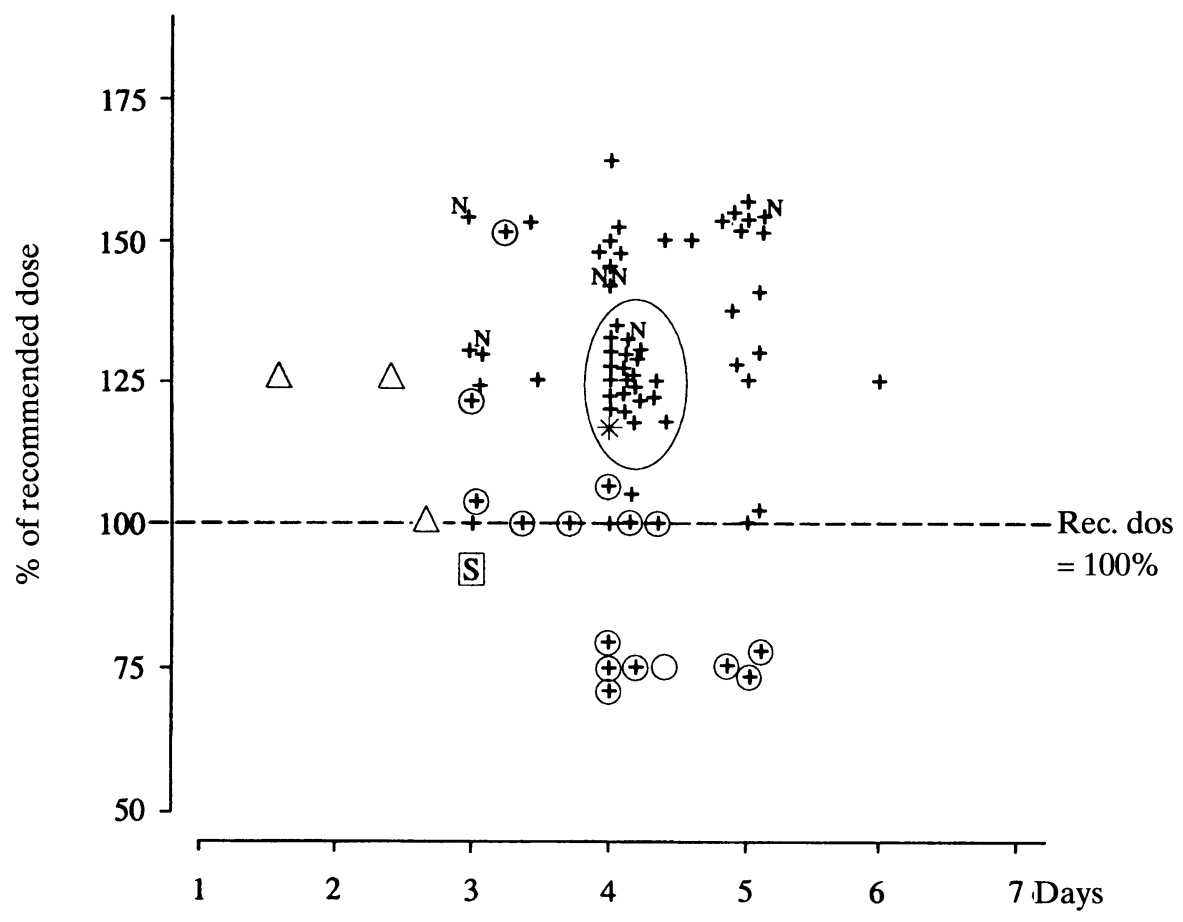

Figure 1. Dose and duration of treatment of a case of acute clinical mastitis. Numbers on the $y-$ axes indicates $\%$ of the recommended dose. Each symbol represents one veterinarians treatment of the case. Only those answers that state both the dose of a specific drug and the duration of treatment are included. $(\mathrm{N}=78)$

\begin{tabular}{llc}
\hline & & Recommended dose/day \\
\hline Benzylpenicillinprocain & (BPP) & $20 \mathrm{mg} / \mathrm{kg}$ \\
Benzylpenicillinpotassium & (BPK) & $9.5 \mathrm{mg} / \mathrm{kg} \mathrm{x} \mathrm{2}$ \\
Dihydrostreptomycin & (DHS) & $25 \mathrm{mg} / \mathrm{kg} \mathrm{x} \mathrm{2}$ \\
Enrofloxacin & (ENRO) & $2.5 \mathrm{mg} / \mathrm{kg}$ \\
Spiramycin & (SPIR) & $8 \mathrm{mg} / \mathrm{kg}$ \\
Tetracyclin & (TETRA) & $10 \mathrm{mg} / \mathrm{kg}$ \\
Trimetoprim/sulfonamide & (TRIM/SULFA) & $20 \mathrm{mg} / \mathrm{kg} \mathrm{x} \mathrm{2}$ \\
Benzylpenicillin ester & (BPE) & $20 \mathrm{mg} / \mathrm{kg}$ \\
\hline
\end{tabular}

Symbols:

$$
\begin{aligned}
& +=\text { BPP } \\
& \mathrm{N}_{+}=\text {BPP }+ \text { BPK (all BPK treatments were done in combination with BPP) } \\
& *=\text { BPP + BPE } \\
& \text { S }=\text { SPIR + SULFA } \\
& \otimes=\text { BPP + DHS } \\
& \Delta=\text { TRIM/SULFA } \\
& 0=\text { DHS }
\end{aligned}
$$


Treatment periods of 3 to 5 days were practised by a vast majority of veterinarians in cases of gram positive infections. In cases of gram negative infections treatments were usually carried out for 2 to 3 days.

At drying off longacting preparations for local administration was used by $60 \%$ of the veterinarians. Benzylpenicillin in combination with streptomycin or framycetin seemed to be the drugs of choice. Fourty percent of the veterinarians combined systemic and local therapy at drying off. Systemic therapy was then used for up to 6 days mostly in combination with the long acting preparations mentioned.

From this study it is obvious that, in the planning and carrying through of treatment trials in the field, special emphasies must be placed on the recordings of anamnestic data, clinical symptoms etc. so that e.g. inclusion and exclusion criteria of animals to the trial may be followed correctly. The fact that veterinarians differ in how and when they apply basic measures and basic therapy must also be considered.

\section{Reference}

Andersson KL, Smith AR, Shankes RD et al.: Efficiency of flunixin meglumine for the treatment of endotoxin-induced bovine mastitis. Amer. J. vet. Res. 1986, 47, 1366.

Anonymous: Djurhälsovård 1974/75. Annual report from the Animal Health Department of Association for Swedish Livestock Breeding and Production. 1975.

Bjorland J, Bakken G, Eidsaa R, Farver TB, Homme $L$, Leine N, Onstad E: A comparison of two dose levels of antibiotics for intramammary treatment of clinical mastitis in cows. Acta vet. scand. 1984, 25, 151-163.

Breeuwsma AJ, Dijkstra RG, Keusters-Klasens $M$, Knijff PC, Osinga A, Pennings A: Comparative studies on the effectiveness of intramammary treatment of clinical mastitis in cattle. Tijdschr. Diergeneesk. 1975, 100, 1193-1206.
Craven $N$ : Efficacy and financial value of antibiotic treatment of bovine clinical mastitis during lactation - a review. Brit. vet. J. 1987, 143, 410422.

Dodd FH, Griffin TK: The role of antibiotic treatment at drying off in the control of mastitis. Proc. JOF Mastitis Seminar, Reading 1985, 282-302.

Ekman T, Funke H, Åström G: Åtgärder vid mastit hos mjölkkor i Sverige. Del 2. Akut mastit. (Steps taken at mastitis in Swedish dairy cows. 2. Acute mastitis). Sv. VetTidn. 1990, 42, 711718.

Ekman T, Funke H, Åström G: Åtgärder vid mastit hos mjölkkor i Sverige. Del 4. Perakut masit. (Steps taken at mastitis in Swedish dairy cows. 4. Peracute mastitis). Sv. VetTidn. 1991, 43, 63-68.

Francis PG: Update on mastitis. III. Mastitis therapy. Brit. vet. J. 1989, 145, 302-311.

Funke H: The distribution of $\mathrm{S}^{35}$-labelled benzylpenicillin in normal and mastitic mammary glands of cows and goats after local and systemic administration. Thesis, Stockholm. Acta vet. scand. 1961, 2, Suppl. 1; 1-88.

Funke $H$ : Intramuskulär behandling av kliniska mastiter (Intramuscular treatment of clinical mastitis). Sv. Vet.tidn. 1979, 31, 582-585.

Funke H: Behandling av kliniska mastiter med Staphylococcus aureus-infektioner. (Treatment of clinical mastitis caused by Staphylococcus aureus). Sv. Vet.tidn. 1983, 35, 713-715.

Funke H, Ekman T, Åström G: Åtgärder vid mastit hos mjölkkor i Sverige. Del 1. Enkät bland distriktsveterinärer om diagnostik och behandling. (Steps taken at mastitis in Swedish diary cows. 1. Inquiry among district veterinarians about diagnosis and treatment). Svensk VetTidn. 1990, 42, 659-661.

Funke, H, Ekman T, Åström G: Åtgärder vid mastit hos mjölkkor i Sverige. Del 5. Kroniska subkliniska mastiter vid sinläggning. (Steps taken at mastitis in Swedish Dairy cows. 5. Cronic subclinical mastitis at drying off). Svensk VetTidn. 1991, 43, 107-111.

Funke H, Ekman T, Åström G: Åtgärder vid mastit hos mjölkkor i Sverige. Del 6. Allmänna frågor slutdiskussion (Steps taken at mastitis in Swedish dairy cows 6 . General questions). Sv. Vettidn. 1991, 43, 151-155.

Holmgren $N$, Häggmar B, Tolling $S$ : A field trial evaluating the use of cefoperazone in the treatment of bovine clinical mastitis. Nord. Vet. Med. 1985, 37, 228-233. 
Jarp J, Bugge HP, Larsen S: Clinical trial of three therapeutic regimes for bovine mastitis. Vet. Rec. 1989, 124, 630-634.

Nickerson SC, Paape MJ, Harmon RJ, Ziv G: Mammary leukocyte response to drug therapy. J. Dairy Sci. 1986, 69, 1733-1742.

Owens WE, Nickerson SC: Treatment of Staphylococcus aureus mastitis with penicillin and novobiocin: Antibiotic concentrations and bacteriologic status in milk and mammary tissue. J. Dairy Sci. 1990, 73, 115-124.

Rasmussen F: Distribution of sulphonamides in the mammary gland of cows after intramammary and intravenous application. Acta vet. scand. 1964, 5, 347-361.

Robertsson JÅ, Franklin A: Antibiotikaresistens hos bakterier isolerade från akuta mastititer på kor. Sv. Vet.tidn. 1987, 39, 115-120.

$\emptyset$ sterås $O$, Aursjø J, Grønningsæeter Gjul G, Jørstad A: The effect of dry cow therapy. An evaluation of long-acting and short-acting intramammaria. 1994, in press.

Åström G, Ekman T, Funke $H$ : Åtgärder vid mastit hos mjölkkor i Sverige. Del 3. Exerbativ mastit. (Steps taken at mastitis in Swedish dairy cows. 3. Exervative mastitis). Sv. VetTidn. 1991, 43, 7-11.

\section{Sammanfattning \\ Åtgärder vidtagna av veterinärer $i$ Sverige vid mastit hos mjölkkor.}

En enkät rörande diagnos och behandling av bovin mastit sändes ut till alla Sveriges 350 distriktsveterinärer. $287(82 \%)$ enkäter returnerades. Ett av huvudsyftena med enkäten var att identifiera en terapiregim som skulle kunna användas som kontrollbehandling vid framtida kliniska försök. Enkäten visade att många faktorer som har betydelse vid diagnostik av bovin mastit, såsom kroppstemperatur, symtomens duration etc ofta inte undersöktes. Å andra sidan framgick att $60-70 \%$ av fältpraktikerna regelbundet tog mjölkprov för att erhålla en bakteriologisk diagnos. Ungefär $40 \%$ av veterinärerna odlade ut mjölkproverna i sitt hemlaboratorium. Basåtgärder, som till exempel täta urmjölkningar, rekommenderades bara av $40-50 \%$ av veterinärerna. Alla svenska fältpraktiker administrerade antibiotika allmänt när de behandlade fall av akut, klinisk mastit. Bensylpenicillinprokain valdes initialt av 65$75 \%$ av veterinärerna vid behandling av sådana fall. Tjugofem procent valde bredspektrum-antibiotika, vanligen en kombination av bensylpenicillin och streptomycin. En minoritet (5\%) riktade sin terapi mot gramnegativa bakterier. Ungefär $30-40 \%$ understödde allmänbehandlingen med intrammär behandling. Andra mediciner som NSAID, kortikosteroider och oxytocin användes regelbundet endast av cirka $10 \%$ av distriktsveterinärerna.

(Received October 6, 1993; accepted March 25, 1994).

Reprints may be requested from: T. Ekman, Department of Obstetrics and Gynaecology, Faculty of Veterinary Medicine, Swedish University of Agricultural Sciences, P.O. Box 7039, S-750 07 Uppsala, Sweden. 